\title{
THE PERFORMATIVE FORCE OF BODIES: AFFECTIVE REALISM IN CONTEMPORARY BRAZILIAN CINEMA
}

\author{
Alessandra Brandão \\ Universidade do Sul de Santa Catarina \\ Florianópolis, SC, BR. \\ Ramayana Lira de Sousa \\ Universidade do Sul de Santa Catarina \\ Florianópolis, SC, BR.
}

\begin{abstract}
This article traces the emergence of a younger generation of Brazilian filmmakers whose works bypass traditional themes in Brazilian cinema such as urban violence and historical revisionism to engage in post-identity politics avoiding narratives of nation, class and gender. One of the most prominent features in these recent works is a questioning of the status of the image, which vacillates between fiction and documentary without a point of resolution. This vacillation can be understood in terms of the performative nature of films like The Monsters, The Residents, The Earth Giveth, The Earth Taketh and Avenida Brasilia Formosa. Such films are centered around improvisations that open up the image to the real. Therefore, these films produce a space between fiction and documentary, between reality and artifice that is productive and politically charged. This article aims at discussing this "Brand New" Brazilian Cinema (Novísssimo Cinema Brasileiro) and the performative force of bodies in its affective realism. No longer a referent for a sociological truth about Brazilian society, realism is taken as something that the image does, i. e., as an affect that challenges the viewer's response-ability.
\end{abstract}

Keywords: Contemporary Brazilian cinema; performance; affect; body.

Words such as aesthetics of hunger, marginality, national allegory, identity, bad consciousness, which were once so useful in discussions about Brazilian cinema, seem to be losing their explanatory power. One reason for the waning importance of this vocabulary is that it has been too often applied in generalizing approaches that ignore the films' singularities and overlook diverse affiliations. The films made by a younger generation of Brazilian filmmakers, by circumventing traditional themes like urban violence and historical revisionism, do not seem to be concerned with "images of Brazil", pointing out to post-identity politics that go beyond narratives of nation, class and gender. Such films demand a critical effort that looks deeply into each work in order to come to more abstract concepts, thus avoiding the methodological pitfall that imposes a Procrustean approach where films are compelled to follow previously established notions. Because this emergent style (and mode of production, as we argue bellow) defies traditional categories employed to talk about Brazilian cinema, we propose to read its realism and the affective force of bodies through the lens of contemporary theory, in the intersection between philosophy and films studies.

\footnotetext{
* Alessandra Brandão was a postdoctoral fellow at the University of Leeds (2012-2013) and is Professor of Film Studies and Literary Theory at the Graduate Program in Language Sciences at Universidade do Sul de Santa Catarina.

${ }^{* *}$ Ramayana Lira de Sousa is Professor of Film and Literary Studies at Universidade do Sul de Santa Catarina. She conducted post-doctoral research at University of Leeds and was a Fulbright grantee in the U.S.
} 
One idea that is dear to Brazilian culture and arts is that of "realism". Brazilian literature, for example, has shown a keen interest in realist and naturalist aesthetics. Aluísio de Azevedo's novel O Cortiço is paradigmatic in this sense. Published in 1890, the book describes the daily life of poor people in Rio de Janeiro, mainly those who inhabited the slums. Azevedo uses a legal maxim as an epigraph: "The Truth, the whole truth and nothing but the truth", thus emphasizing a desire to come closer to some "social truth" that art could reveal. As Brazilian critic Flora Sussekind suggests, novels like O Cortiço seem to look for a meaning beyond itself, in the extraliterary context, masking its fictionality in the name of a greater referentiality, akin to scientific and journalistic models (37). Language, here, would grant access to the extra-textual world, and the writer would become a dispassionate observer. Sussekind observes how this tendency recurred in Brazilian literature in the 1880s, 1930s and 1970s. Such continuity, we would like to argue, can also be extended to a part of the production in contemporary Brazilian cinema.

When considering the issue of a naturalistic aesthetic in film, Ismail Xavier sketches the concept as an effort to faithfully reproduce the physical world and human behaviour, as if the audience was directly in touch with the world. Filmic discourse would then be "natural", a transparent medium revealing reality. The renewed interest for this kind of "immediate" discourse is materialised in what Leonardo Mecchi calls "Brazilian Popular Cinema" of the twenty-first century. Mecchi surveys top box office hits and comes to the conclusion that most of these works fall in the category of what he calls "film-verism", i.e., the affirmation of cultural legitimacy by appealing to the representation of an aspect of Brazilian reality.

This has been the dominant perspective: in filmic narratives since the 1990s, poverty and violence are consumed as "typical" or "natural" constituents: in such view there is nothing one can do about them. Films such as City of God (Cidade de Deus), Lower City (Cidade Baixa), Mango Yellow (Amarelo Manga) and Elite Squad (Tropa de Elite) tend to portray violence by appealing to a "real" constructed as "immediate", as if the characters where directly "denouncing" reality.
However, a new generation of filmmakers proposes new forms and themes where, no longer a referent for a sociological "truth" about Brazilian society, realism is taken as something that the image does, i. e., as an affect that challenges the viewer's "response-ability" (to use the terminology developed by Marco Abel in Violent Affect: Literature, Cinema, and Critique After Representation).

One of the most prominent features in these recent works is the questioning of the status of the image, which vacillates between fiction and documentary without a point of resolution. This vacillation can be understood in terms of the performative nature of films like The Monsters (Os Monstros, 2011, directed by Luiz and Ricardo Pretti, Guto Parente, and Pedro Diógenes), The Residents (Os Residentes, 2010, directed by Tiago Mata Machado), The Earth Giveth, The Earth Taketh (Terra Deu, Terra Come, 2010, directed by Rodrigo Siqueira) and Avenida Brasília Formosa (2010, directed by Gabriel Mascaro). Such films are centered around improvisations that open up the image to the real. Therefore, these films produce a space between fiction and documentary, between reality and artifice that is productive and politically charged. Moreover, the actors's bodies is the site where most of this affective realism is produced, as they reverberate Elena Del Rio's description of "the material and sensual aspects of the body as capable not only of receiving, but also of acting upon, the structuration of meaning in the cinema" (2). We, thus, intend to discuss this "Brand New" Brazilian Cinema (Novísssimo Cinema Brasileiro) and the performative force of its affective realism.

Let us first explain what we call the "Brand New" Brazilian Cinema. The expression Novíssimo Cinema Brasileiro has been used by film critics in Brazil to describe the emergence of new directors, but it would be misleading to say it bears any connection with Brazilian New Cinema (Cinema Novo), either in aesthetic or in political terms. It is, in a way, a tendency that is itself interstitial. Neither an industrial product aiming at massive audiences nor part of a tradition of political/ critical films which characterized a fraction of the production in Brazil since the mid 1960s, this Brand New Cinema invests in authorial works, often organized 
around a group of friends or collectives, and gives special attention to small events, daily life and delicate bonds. Therefore, we are using the expression to describe a new generation of filmmakers whose logic of production and circulation is relatively independent from industrial patterns. Their films are mostly funded by public money, via tax waivers and direct financing coming from regional and national announcements. Some, however, are completely independent from public money. The table below (Table 1) shows in further detail to which extent some of the "Brand New" Brazilian Cinema films count on tax waivers for their production.

Table 1

The Brand New Brazilian Cinema mode of production (values in Brazilian Real)

\begin{tabular}{|c|c|c|c|c|c|c|c|}
\hline Title & Director & Producer & Region & Genre & $\begin{array}{l}\text { Total Budget } \\
\text { Tax Waiver }\end{array}$ & Box office & Attendance \\
\hline A Alegria & $\begin{array}{l}\text { Felipe Bragança e } \\
\text { Marina Meliande }\end{array}$ & $\begin{array}{l}\text { DM Filmes e Produções } \\
\text { Artísticas }\end{array}$ & RJ & Fiction & $877.812,36$ & $28.517,15$ & 3.108 \\
\hline $\begin{array}{l}\text { A Casa de } \\
\text { Sandro }\end{array}$ & Gustavo Beck & Costa Mecchi. & SP & Doc & - & 350,00 & 55 \\
\hline $\begin{array}{l}\text { A Falta que Nos } \\
\text { Move }\end{array}$ & Christiane Jatahy & Tambellini Filmes & RJ & Fiction & $1.144 .229,22$ & $81.524,00$ & 7.475 \\
\hline $\begin{array}{l}\text { A Fuga da Mul- } \\
\text { her Gorila }\end{array}$ & $\begin{array}{l}\text { Felipe Bragança e } \\
\text { Marina Meliande }\end{array}$ & $\begin{array}{l}\text { DM Filmes e Produções } \\
\text { Artísticas }\end{array}$ & RJ & Fiction & - & $1.862,50$ & 384 \\
\hline $\begin{array}{l}\text { Avenida Brasília } \\
\text { Formosa }\end{array}$ & Gabriel Mascaro & $\begin{array}{l}\text { Plano } 9 \text { Produções Audiovi- } \\
\text { suais Ltda. }\end{array}$ & $\mathrm{PE}$ & Doc & - & $4.021,00$ & 999 \\
\hline Belair & $\begin{array}{l}\text { Bruno Safadi e Noa } \\
\text { Bressane }\end{array}$ & TB Produções & RJ & Doc & $1.148 .500,88$ & $8.826,70$ & 1.072 \\
\hline $\begin{array}{l}\text { Chantal Aker- } \\
\text { man, de Cá }\end{array}$ & $\begin{array}{l}\text { Gustavo Beck e } \\
\text { Leonardo Luiz } \\
\text { Ferreira }\end{array}$ & Costa Mecchi. & SP & Doc & - & $1.304,50$ & 235 \\
\hline Desassossego & Collective & $\begin{array}{l}\text { DM Filmes e Produções } \\
\text { Artísticas }\end{array}$ & RJ & Fiction & - & $1.419,00$ & 350 \\
\hline $\begin{array}{l}\text { Estrada para } \\
\text { Ythaca }\end{array}$ & $\begin{array}{l}\text { Guto Parente, } \\
\text { Luiz Pretti, Pedro } \\
\text { Diógenes e Ricardo } \\
\text { Pretti }\end{array}$ & $\begin{array}{l}\text { Alumbramento Produções } \\
\text { Cinematográficas Ltda. }\end{array}$ & $\mathrm{CE}$ & Fiction & - & $5.348,50$ & 830 \\
\hline Morro do Céu & Gustavo Spolidoro & Gustavo Spolidoro & RS & Doc & - & $1.193,00$ & 210 \\
\hline $\begin{array}{l}\text { O Céu Sobre os } \\
\text { Ombros }\end{array}$ & Sérgio Borges & Orobó Filmes Ltda. & MG & Fiction & - & $25.077,66$ & 3.094 \\
\hline Os Monstros & $\begin{array}{l}\text { Guto Parente, } \\
\text { Luiz Pretti, Pedro } \\
\text { Diógenes e Ricardo } \\
\text { Pretti }\end{array}$ & $\begin{array}{l}\text { Alumbramento Produções } \\
\text { Cinematográficas Ltda. }\end{array}$ & $\mathrm{CE}$ & Fiction & - & $1.714,00$ & 353 \\
\hline Os Residentes & $\begin{array}{l}\text { Thiago Mata } \\
\text { Machado }\end{array}$ & Filmes do Cerrado Ltda. & MG & Fiction & $996.004,04$ & $1.877,00$ & 550 \\
\hline Pacific & Marcelo Pedroso & Símio Filmes Ltda. & $\mathrm{PE}$ & Doc & - & $2.922,50$ & 638 \\
\hline Riscado & Gustavo Pizzi & Cavideo & RJ & Fiction & $170.000,00$ & $37.396,05$ & 4.303 \\
\hline Trabalhar Cansa & $\begin{array}{l}\text { Juliana Rojas e } \\
\text { Marco Dutra }\end{array}$ & $\begin{array}{l}\text { Dezenove Som e Imagens } \\
\text { Produções }\end{array}$ & SP & Fiction & $2.669 .603,31$ & $67.951,20$ & 6.687 \\
\hline Transeunte & Eryk Rocha & Videofilmes & RJ & Fiction & $2.374 .893,10$ & $13.541,42$ & 1.724 \\
\hline $\begin{array}{l}\text { Os Famosos e } \\
\text { os Duendes da } \\
\text { Morte }\end{array}$ & Esmir Filho & $\begin{array}{l}\text { Dezenove Som e Imagens } \\
\text { Produções }\end{array}$ & SP & Fiction & $4.243 .586,13$ & $64.897,00$ & 7.747 \\
\hline
\end{tabular}




\begin{tabular}{|l|l|l|l|l|l|l|l|}
\hline $\begin{array}{l}\text { Terra Deu, } \\
\text { Terra Come }\end{array}$ & Rodrigo Siqueira & $\begin{array}{l}\text { C R Produções - Foto, Cine- } \\
\text { Vídeo Ltda. / TZ Editora E } \\
\text { Produtora Ltda. }\end{array}$ & SP & Doc & $157.866,89$ & $14.890,00$ & 1.692 \\
\hline $\begin{array}{l}\text { Um Lugar ao } \\
\text { Sol }\end{array}$ & Gabriel Mascaro & Símio Filmes Ltda. & PE & Doc & - & $9.312,00$ & 1.809 \\
\hline No Meu Lugar & Eduardo Valente & Videofilmes & RJ & Fiction & $3.515 .844,35$ & $31.520,86$ & 5.227 \\
\hline
\end{tabular}

Source: ANCINE (Agência Nacional de Cinema).

As we can see, these are modestly budgeted films that enjoy limited commercial circulation, even though they can be watched on public and cable TV (though not on primetime) or through alternative means of distribution. For example, O Céu Sobre os Ombros and Avenida Brasília Formosa were distributed accompanying a volume of Piauí, a monthly magazine in Brazil.

Another striking feature of this generation are the collective efforts in the process of filmmaking. The Monsters, for example, is directed by four people, two brothers and two cousins, who also wrote and acted in the film. O Céu Sobre os Ombros was created in the ebullient environment of Teia, a collective in Minas Gerais. Although it would be precipitated to say that the notion of authorship has disappeared in these artistic endeavors, it is important to bear in mind that younger filmmakers are distancing themselves from the tradition of the struggling individual artist and of the director who speaks for a subaltern group (so closely associated with the 1960s and 1970s generations). As a matter of fact, contemporary films do not carry out totalizing discourses about individual or groups nor do they seem to reach any encompassing interpretation of the nation, opting for singular configurations, not allegorical ones.

Furthermore, the Brand New Cinema we are describing reconfigures "realism" and performance, thus advancing a new way to understand how cinema relates to the real. Laura Cull acknowledges the difficulty in establishing a stable definition for performance (3), although Richard Schechner suggests that "performances are make-believe, in play, for fun. Or, as Victor Turner said, in the subjunctive mood, the famous 'as if" (xvii). We are interested in the "as if" as a productive operator. What is produced in each film is specific to the individual work but there seems to be a process in common, an impulse that questions what the image does and how bodies reconfigure and are reconfigured by the real.

Performance assumes a disconcerting effect in contemporary Brazilian cinema that challenges narrative, social or historical "truths", as in Avenida Brasilia Formosa and The Earth Giveth, The Earth Taketh, and often presents obstacle to narrative progression and to the flow of "the real" in works like The Monsters and The Residents. Performance, thus, questions the frontiers not only between documentary and fiction, between reality and artifice, but also between gesture and representation. Alain Badiou argues that the cinematographic image has the potential to achieve syntheses between constructed time and pure duration, the sensible and the intelligible, art and industry (4042). In the Brand New Brazilian cinema, each film has a particular way to achieve a synthesis, in this particular discussion, between performance and image, reality and artifice, film and life, body and image.

Let's take The Residents, for example. In Tiago Mata Machado's film we have a troupe of young actors confined to a house that is about to be demolished. The film is structured in semi-independent sequences that describe how, installed in a new temporary autonomous zone, the residents spend their days among small plots, quixotic farces and semi-Romantic delusions. The characters make of their self-imposed exile in the ruins an opportunity to engage in an experience of excess, an attempt, indeed, to deal with the decline of experience in a world that seems to have diluted life into inauthentic gestures and poses. The troupe, thus, is aware that authenticity is no longer available as a value against which we could measure the efficacy of art; indeed, the residents search for some truth that never comes, always deferred by their attempts at reviving the avant-garde. Their plots and conversations are spatially constrained by four walls, in a mise-en-scène that forms 
a kind of theatre where the actors perform the ultimate failure of their artistic ambitions. Mourning comes in the guise of farce, as their aesthetic research eventually fails to deliver anything new.

It is this prolonged waiting in isolation and the confinement to the abandoned house that generates a crisis in the image. In The Residents we do not have a narrative line that progresses and the confined spaces of performance are, as we said, relatively autonomous. Each sequence, in a way, represents an ephemeral moment of success in the struggle against the inefficacy of art, only to be succeeded by more waiting. The plans are pretentious, but actions fail to have any consequence. This is the game that film creates for us, spectators, a game of cat and mouse where, like Tom and Jerry, we apparently have a winner at the end of each episode, only to be revived in the next segment, starting from the beginning, going nowhere.

Schechner reminds us of the close-knit association between performance and game. In the case of Machado's film, the game/performance privileges the time of bodies and gestures rather than the causal/functional narrative order. Time is, to a certain extent, unproductive, as we can only extract from it a few consequences and chain of events. It is a dérive, in situationist terms. It is such temporality that allows for objects like pubic hair to become something else: a moustache. In one of the sequences of the film, a man cuts his girlfriend's pubic hair and uses it as a moustache. In the following sequence it is she who is wearing the unusual facial hair. It is not only a humorous metamorphosis or the inversion of values (from pubis to face, from private to public, female to male, erotic to farce). Actually, this temporality helps dilute such values in as much as the transposition from one sequence to the other does not amount to a teleology determining that one state is better than the other.

The rarefied narrative coherence is a principle that is also expressed by one of the characters, who says life should be like a game, its everydayness experimentally constructed from deliberately prepared perishable moments only ephemerally successful. This is, of course, a quote from Guy Debord's 1958 “Theses on cultural Revolution", which reads:

\begin{abstract}
The situationist goal is immediate participation in a passionate abundance of life, through the variation of fleeting moments resolutely arranged. The success of these moments can only be their passing effect. Situationists consider cultural activity, from the standpoint of totality, as an experimental method for constructing daily life, which can be permanently developed with the extension of leisure and the disappearance of the division of labor (beginning with the division of artistic labor). (Debord 61)
\end{abstract}

In this scene, one of the residents (played by Gustavo Jahn) has apparently kidnapped a young woman who is kept tied down in a bathtub as he indoctrinates her while he defecates in the toilet. Jahn's deadpan delivery carries no sign of passion, whether for a cause or for the woman, and the final act of cleaning his ass with the pages from the book indicates that the film privileges "lived" rather than "theoretical" experiences. Words are worth shit. Actions should speak volumes. Nevertheless, when bodies "act" in the film they neither provide us with some truth nor engage in alienating artificiality. The bodies "act" in a space that is between naturalistic, psychologically motivated impersonation and pure simulacrum.

If we go back to the late 1960s and early 1970s, we will be able to trace a sort of lineage for The Residents, as Carlos Alberto Matos points out. Films such as Gamal, o Delírio do Sexo (1970), directed by Joaquim Pedro de Andrade, Hitler Terceiro Mundo (1968), by José Agrippino de Paula, and Sem Essa, Aranha (1970), by Rogério Sganzerla, were also grounded on performances, often in open air, for the surprise-and sometimes chagrin-of passersby. Intervention in public spaces was both a mode of production and a strategy of survival: it worked as a means to achieve direct contact with reality but its hurried and improvised nature was also a response to the repression of the dictatorial regime then in force. By the same token, these interventions worked as criticism of Cinema Novo's attempts to produce a rational representation of Brazil (Matos 103).

Irrationality, ephemerality, direct affront were, thus, in the very core of the political-aesthetic project of the aforementioned films. Recent productions like The Residents take on this project, but introduce a set 
of transformations. Performance, here, is carried out with an evidently polished finish which can be seen in the care taken with cinematography and art direction, a care that was foreign to the early 1970s cinema. Moreover, the direct affront, the deliberate intervention in collective spaces gives place to empty streets and closed rooms (Matos 103). In a sense, contemporary Brazilian cinema is much more centered around actors and their characters, and public spaces become a stage for their individual performances. The fact that a number of these films is made by groups of friends conveys an obsessive self-referentiality that calls for a reconsideration of the film's political potential.

One of the possible repercussions of the powers of performance and bodily presence in this film is a blurring in the (always artificial) frontiers between art and life. Performance, thus, becomes a kind of theatricalization of life that expands art beyond the limits of narrative economy. Time, for example, is not imposed by narrative or functional demands, but it is a direct effect of the ritual entailed in the performance. Realism has to be thought in terms of the bodies that occupy the screen with their "affected" gestures, that is, anti-naturalist oil of psychological motivation and direct social commentary. In The Residents, in particular, we have a 15 minute sequence of a couple of actors (Melissa Dullius and Gustavo Jahn), both artists, and married in real life, discussing their relationship. The same distention of time can be found in the last scene of The Monsters, a long improvisation of jazz music.

As in The Residents, The Monsters is also concerned with the relationship between art and life. In the beginning of the film, directed by Luiz and Ricardo Pretti, Guto Parente and Pedro Diógenes, light struggles against dark: the film's first shots are of the lonely figure of a musician, against the evening cityscape, playing dissonantly, thus anticipating one of the most important issues in the film-the tension between artistic tradition and individual expression. The musician's silhouette, barely perceptible in the horizon, resists being engulfed by the dark, and the howl of saxophone questions the limits of musicality.

The Monsters, however, is also a film about waiting, about preparation. A musician and two friends, sound technicians dissatisfied with their job in a clichéd audiovisual production, wander through the city, go to parties, get drunk, in a thin narrative line that can be understood as a prologue to the real meeting, the real communion, the moment when a second musician appears and the four friends can eventually set up a jam session that lasts for the whole last quarter of the film.

Collective work, in the filmmaking and in the musical performance, is a manifestation of the film's affective force. The Monsters is grounded on an aporia: on the one hand, its investment in collective creation dissolves individual authorship; on the other hand, the film reinforces a romantic notion of the misunderstood genius. That is the case, for instance, in the sequence where the musician loses his place at the club where he plays for a duo who sings soft pop Brazilian songs. There is an evident contrast between a creative effort and the mere reproduction of clichés. The three wandering musketeers search for purity, freedom of expression, which they associate with the notion of an "enamored amateur". The directors' creative attitude in defense of an "amateur" cinema is akin to Marguerite Duras' own approach which opposes the luxury, superficiality and futility of "professional" cinema. Duras said that her cinema could not go beyond the professionals' frontier. And neither could their cinema go beyond her frontier. By professionals she meant those who reproduce cinema, like those who reproduce paintings in opposition to cinema auteurs (qtd. in Aumont 163).

It is, then, as a moment of pure creation that performance operates in The Monsters. Creation becomes a matter of sharing an instant, of a good encounter, where the rigor to achieve an accomplished product is not as important as the process where the image is put at risk because it is imbricated in the creation of a world. All these intensities are released in the final sequence, where we have a very long take of a musical presentation. The film incorporates risk and chance, fixating the performers' bodies in the music's abstract temporality. There is no ritual, bodies do not reenact gestures, what we have is a radical openness to the world. Furthermore, the evident exhaustion of the bodies due to the prolonged musical performance brings to light the matter of an ethics of realism, as discussed by Lucia Nagib. For Nagib, the bodily 
commitment of cast and crew in long takes demanding physical effort reveals, rather than symbiosis with fictional characters, "an engagement with a real context" (32). This engagement "relates to contingency, rather than narrative mimesis, with presentation of reality as it happens, rather than representation, and this is where commitment translates into an ethics" (32).

French critic André Bazin, when writing about Jean Renoir, said that the movement towards the real can take many different routes and that celebrating realism per se meant nothing. Such movement, Bazin argued, is relevant only when it begets an amplified meaning to what is created (85). Performance in The Residents and The Monsters, based on play and affect, produces such an amplification of this movement towards the real that, instead of begetting meaning, a clear legibility, the films eventually destabilize it. They offer a vacillating ontology, a becoming, we could say, where the real is being created along with the image.

Elena del Rio comments about performance that "in its fundamental ontological sense, performance gives rise to the real. While representation is mimetic, performance is creative and ontogenetic" (4). So performance in contemporary Brazilian cinema is not a matter of registering the ephemeral, but of creating something new, new affects, new worlds. Both in The Residents and in The Monsters the actors' bodies are extracting something new from the image in a process that Elena del Rio summarises as such: "Thus the body simultaneously figures as a normative structure regulated by binary power relations (on a molar plane of formed subjects and identities) and as an excessive, destabilizing intensity responsive to its own forces and capacities (on a molecular plane of impersonal and unformed becomings)" (9). Del Rio also dismisses the idea that the performative force of films would be restricted to certain genres or filmic forms. She says:

Rather than depending upon a particular kind of film (a estabilizing condition inimical to the very disruptive function of the affectiveperformative), the eruption of affectiveperformative moments is a matter of a constantly fluctuating distribution of degrees of intensity between two series of images: those belonging to explainable narrative structures, and those that disorganize these structures with the force of affective-performative events. (15)

Therefore, both fiction and documentary films can be affected by the forces of performance. Indeed, if we take some of the recent documentary films produced by young filmmakers in Brazil, we will be able to see that performance is in the very core of a profound critique of truth. These films allow us to observe that not only does performance disorganize narrative strictures, as proposed by Del Rio, but it is also a function of the image: we could say that the image itself is "performing" something.

Avenida Brasília Formosa, directed by Gabriel Mascaro, depicts the changes in urban spaces in a poor, centrally located district in the Brazilian city of Recife. The favela Brasília Teimosa (Stubborn Brasília) is planted in the heart of one of the most expensive beaches in Recife, and it has been changing since the simple houses by the beach had to give way for a motorway. The film explores how the local inhabitants experience life and their dreams. The main characters are a local barkeeper who also makes videos of parties and weddings, a hairdresser who commissions him a video to submit to the Big Brother TV program, an elderly fisherman, and a young schoolboy. The film blurs the boundaries between fiction and documentary as these people play themselves in situations suggested by the director, situations that loosely make up a story and allow their lives to race past each other.

Mascaro's film patiently captures snapshots of the district. People, houses, streetlights, animals, everything is observed with the same detachment. Claudia Mesquita and André Brasil note that what is at stake in the film is a "work of immanence" (234), a close contiguity of the image with the world. The image is performing this contiguity, open as it is to the world (thanks to a distention of time created by a very discrete editing): the film engenders and is engendered by the lives that it is depicting. Working at a molecular level, Avenida Brasília Formosa does not "explain" the social evils of life in the slums. If it has any similarity with Aluísio de Azevedo's O Cortiço, mentioned in the beginning of this article and which portrays the decayed 
urban areas of nineteenth century Rio de Janeiro, it is the fact that both works explore multiple characters in their connection with the milieu they live in. However, the impulse to tell things as they are ("Hoc est verum et nihili nisi verum"), which characterizes the novel, is totally avoided by Mascaro's film: Avenida Brasília Formosa refuses to judge society.

But that does not mean that it is politically void. By the end of the film we are presented with the images of the Big Brother video. The images we have are, to an extent, a molar composition, to use Del Rio's term borrowed from Gilles Deleuze and Felix Guattari to discuss the powers of affection in cinematicc performance. They are cliched images that imprison the bodies in stereotypical gestures. The fight, here, is not only against narrative coherence, not only a fight of the image against the verb, as Del Rio's theorization suggests. What is at stake, here, is how the image folds itself and, by freeing itself from cliches, it is able to create something. Bracketed between the everydayness that is portrayed in the film, the Big Brother audition video exposes the gestures that have been captured by television formulae, thus emphasizing the richness of the world that is created by the characters in their performances instead of the world created for them by TV.

The Earth Giveth, The Earth Taketh is another example of how performance comes to destabilize molar structures. In the film, Pedro de Almeida is an 81 year-old prospector who works as a master of ceremony at his friend João Batista's funeral. The deceased is said to be 120 years-old. The ceremony takes place in the backlands of Minas Gerais, a region famous for diamond extraction and for communities descendent from African slaves. The funeral lasts 17 hours and ends with the burial during which Pedro sings burial songs in the African Banguela dialect. He is one of last people to have any memory of these songs. Pedro was a lucky prospector: he found many diamonds. But he was an unlucky investor and had lost most of his money. His first diamond, however, which he prospected with his uncle, disappeared after the uncle died. To locate this diamond he has to conjure his uncle's spirit.

The film is organized around Pedro's performance as a storyteller and priest. His stories and rituals always carry a poetic challenge to our senses: is what we see true? His and his family's self mise-en-scène is intriguing. It suspends the division between truth and falsification, fact and representation, documentary and fictions, film and life. At some point in the film Pedro talks about a contract, a contract between the dead man and the spirits, and he says once you sign it, there is no going back. But the film ironically subverts the contract with the spectator. From the beginning, we come to acknowledge that there is something "magical", some sort of witchcraft in the moving image. This witchcraft, it will be later revealed in the film, is not so much a direct apprehension of the real, as in classical documentary, but the fabrication of real that is founded on the performative force of bodies.

Pedro de Almeida performs in a ritual where his body is taken by an "entity", his uncle's spirit, who denies knowing Pedro. His wife plays the game with him, accepting the performance. In a way, as spectators, we are at his mercy: is he playing with us, making us believe that he actually believes that his uncle's spirit is present? What are the rules of his games? We are left with no answers. His performance eclipses the molar narrative structure of identity and history. The narrative of dispossession and exploitation, often associated with racial, national and religious identities is put into question by the performance. Differently from classical reenactment documentaries, performance in The Earth Giveth, The Earth Taketh is not a means to reach some essential truth about subjects; it constitutes de very core of the image.

We would like to make a quick reference to Glauber Rocha's Black God White Devil (Deus e o Diabo na Terra do Sol, 1964). At a certain moment of Rocha's film, Corisco, the bandit who is also an ideologue, is shown through a series of jump cuts, leaping backwards. Moments later, as he is dying he shouts "Stronger are the powers of the people". This sequence explores the Enlightenment project that underlies much of Cinema Novo's project. The Earth Giveth, The Earth Taketh visually resembles those scenes from Rocha's film, as Pedro is shown dancing and jumping in shots that are remarkably similar to Corisco's death. However, Pedro shouts "Greater is the power of God". The film opposes rationalism with a ritual that is, nonetheless, 
a challenge to the apparatus. Pedro is aware of the camera, he performs for it as if knowing that is able to register this world shared by the living and the dead, matter and spirit, life and cinema in a communion that makes it difficult to tell one from the other.

These are some of the possible lines of force of a realism that is being refashioned in recent Brazilian films. These works are marked by an in-betweenness at the intersection of the impulse to keep a certain distance in order to see the world and to be immersed in it, in its intensities. They make us face paradoxes but do not immobilize us; on the contrary, they "com-move" us with their contradictory forces. A question that can be proposed, at this point, is exactly how to grasp political configurations from such dispersive, fragmented, diffuse forces. Dispersion seems to evoke dissolution. Subtlety can look like weakness, impotence. But only if we ignore the powers of affect. Caught between molecular organizations and molar structures/strictures, between a "real" that can be immediately grasped through an image that revels in its transparency and a world that is created by the unfolding of lives and bodies in front of the camera, the Brand New Brazilian cinema offers an anti-teleological fluctuation whose finality is not a "revelation", in the sense of a narrative or historicalsociological truth (or even in religious terms). It rests in-between, a space valued by Georges Didi-Huberman located between the certainty of tautology and the unshaken truth of faith. The performative force of bodies in the films we discussed invites us to question what the image is doing rather than what it means: the image of a body is more than just the image of a body (the tautological approach), but it is also much less than a truth about the bodies. Cinematic realism is, thus, reconfigured and its role in the tradition of the Brazilian cinema requires urgent reconsideration.

\section{References}

Abel, Marco. Violent Affect: Literature, Cinema, and Critique After Representation. Lincoln: University of Nebraska, 2008.

ANCINE. Observatório Brasileiro do Cinema e Audiovisual. 4 Nov $2012<$ http://oca.ancine.gov.br/ producao_.htm $>$.

Aumont, Jacques. A teoria dos cineastas. Campinas: Papirus, 2004.

Avenida Brasília Formosa. Dir. Gabriel Mascaro. Perf. Cauan Fonseca, Fábio Gomes de Melo, Alexandro José de Oliveira and Débora Leite. Vitrine Filmes, 2010. $35 \mathrm{~mm}$.

Azevedo, Aluísio. O Cortiço. 22 Sep 2008. <http://www. dominiopublico.gov.br/download/texto/bv000015. pdf>

Badiou, Alain. "El cine como experimentación filosófica." Pensar el cine 1. Imagen, ética y filosofia. Ed. Gerardo Yoel. Buenos Aires: Manantial, 2004. 23-81

Bazin, André. Jean Renoir. Cambridge: First Da Capo Press, 1992.

Black God, White Devil. Dir. Glauber Rocha. Perf. Geraldo Del Rey, Yoná Magalhães, Othon Bastos.1964. Versátil, 2005. DVD.

Cull, Laura. "Introduction.” Deleuze and Performance. Ed. Laura Cull. Edinburgh: Edinburgh UP, 2009. 1-21.

Debord, Guy. "Theses on Cultural Revolution". Guy Debord and the Situationists International-Texts and Documents. Ed. Tom McDonough. Cambridge: MIT Press, 2002. 61-65.

Didi-Huberman, Georges. O que vemos, o que nos olha. São Paulo: Ed. 34, 1998.

Del Rio, Elena. Deleuze and the Cinemas of Performance: Powers of Affection. Edinburgh: Edinburgh UP, 2008.

Matos, Carlos Alberto. "Gregarismo e Teatralidade". Cinema de Garagem - Panorama da Produção Brasileira Independente do Novo Século. Eds. Marcelo Ikeda and Dellani Lima. Rio de Janeiro: WSET Multimídia, 2012. 95-108.

Mecchi, Leonardo. "O Cinema Popular Brasileiro do Século 21”. 03 Sep 2008.< http:// www.revistacinetica. com.br/cinemapopular1.htm>

Mesquita, Claudia, and André Brasil. “'O Meio Bebeu o Fim Como o Mata-borrão Bebeu a Tinta’: Notas sobre O Céu Sobre os Ombros e Avenida Brasília Formosa". Políticas dos Cinemas Latino-Americanos Contemporâneos. Eds. Alessandra Brandão, Dilma Juliano and Ramayana Lira. Palhoça: Ed. Unisul, 2012. 231-248. 
Nagib, Lucia. World Cinema and the Ethics of Realism. New York and London: Continuum, 2011.

The Monsters. Dir. Luiz and Ricardo Pretti, Guto Parente, and Pedro Diógenes. Perf. Luiz and Ricardo Pretti, Guto Parente, and Pedro Diógenes. Vitrine Filmes, $2011.35 \mathrm{~mm}$.

The Residents. Dir. Tiago Mata Machado. Perf. Melissa Dullius, Gustavo Jahn, Jeane Doucas, Simone Sales de Alcântara, Dellani Lima, Roberto de Oliveira, Geraldo Peninha, and Cassiel Rodrigues. Vitrine Filmes, 2010. $35 \mathrm{~mm}$.

Schechner, Richard. Performance Theory. London and New York: Routledge, 2004.

Süssekind, Flora. Tal Brasil, Qual Romance? Rio de Janeiro: Achiamé, 1984.

The Earth Giveth, The Earth Taketh. Dir. Rodrigo Siqueira. Perf. Pedro Vieira. Videofilmes, 2010. 35mm.

Xavier, Ismail. O discurso cinematográfico: a opacidade e a transparência. São Paulo: Paz e Terra, 2005.

Recebido em: 18/06/2015

Aceito em: 14/09/2015 